\author{
Galina Zavarika \\ PhD (Geography), Associate Professor of Department of International Economic and Tourism \\ e-mail: dgalina_10@ukr.net, ORCID ID: https://orcid.org/0000-0001-5601-9331 \\ Volodymyr Dahl East Ukrainian National University, Donetska str., 43, Severodonetsk, 93406, Ukraine
}

\title{
TRANSFORMATION OF TOURISM OF THE EASTERN UKRAINE IN THE CONTEXT OF A CONFLICT
}

\begin{abstract}
The impact of conflict on tourism has been analized in the paper. The purpose of the work is to identify the transformational changes in the state of tourism in the east of Ukraine as a result of the conflict. Analytical, deductive, statistical, systemic, comparative-geographic methods of research have been used to analyze the main indicators of tourism development. It has been proved that all types of tourism suffer from the conflict, and the total number of tourists was significantly reduced. The conflict has once set a promising direction for the economic development of the eastern regions of Ukraine on the brink of total disappearance. The necessity of studying the experience of eliminating the negative consequences of conflicts on the development of the tourism industry and developing a strategy for its further development in the Donetsk and Luhansk regions has been established. For the first time a comprehensive analysis of the status of Donbass tourism in different periods has been conducted, namely: on the eve of the conflict and during the conflict, which showed that staying Ukraine in a state of a conflict led to the emergence of new social and geographical peculiarities of tourism development in the east of Ukraine. It has been revealed that the conflict leads to instability in the development of tourism, tourists worrying about their safety refuse to visit a country or region. This inevitably leads to a decrease in the number of international tourist arrivals and revenues from tourism, a decrease in the number of tourist objects and collective accommodation facilities. It has been determined that the tourist attractiveness and image of the eastern region was almost lost as a result of the conflict. The main provisions, the actual material and conclusions of the article can be used for further research on the development of tourism in the Donbas and the creation of a concept for overcoming the negative consequences of the conflict in the period of 2014-2018 in Ukraine for the development of the national tourism industry.
\end{abstract}

Keywords: tourism, conflict, tourist flow, image, risk.

\section{Галина Заваріка. ТРАНСФОРМАЦІЯ ТУРИЗМУ СХОДУ УКРӒ̈НИ В УМОВАХ КОНФЛІКТУ}

В статті проведено аналіз стану туризму в Донецькій та Луганській областях напередодні та в період конфлікту. 3'ясовано, що туризм зазнав значних негативних змін у своєму розвитку, відбулося значне зниження туристичних потоків у східних областях, зменшилася кількість туристичних об'єктів, колективних засобів розміщення. Визначено, що туристична привабливість та імідж регіону майже втрачено в результаті конфлікту. Виділено перелік основних негативних наслідків впливу конфлікту на туризм як на сході так і загалом в Україні

Ключові слова: туризм, конфлікт, туристичний потік, імідж, ризик.

\section{Галина Заварика. ТРАНСФОРМАЦИЯ ТУРИЗМА ВОСТОКА УКРАИНЫ В УСЛОВИЯХ КОНФЛИКТА}

В статье проведен анализ туризма в Донецкой и Луганской областях накануне и в период конфликта. Выяснено, что туризм претерпел значительные негативные изменения в своем развитии, произошло значительное снижение туристических потоков в восточных областях, уменьшилось количество туристических объектов, мест коллективного размещения. Определено, что туристическая привлекательность и имидж региона почти утрачены в результате конфликта. Выделено перечень основных негативных последствий влияния конфликта на туризм как на востоке так и в целом в Украине.

Ключевые слова: туризм, конфликт, туристический поток, имидж, риск.

Introduction. Not the last place among a large number of tourism problems is the conflict in the East of the country. It sows panic and does not help attract tourists.

The conflict has already caused Ukraine considerable social, demographic, environmental and economic problems that undoutly will be reflected in tourism, they have already led to a significant reduction in tourist flows not only in the eastern regions, but also throughout the country.

The annexation of the Crimea, events in the east and south of Ukraine today caused changes in the structure and volumes of external and internal tourism flows. The occupation of the Crimea led to the loss of about $30 \%$ of the recreational and tourist potential.

The problem is also the increased level of instability in a global scale, the terrorist threat to tourists, in particular in relatively stable economically developed coun- tries, which could not even be thought of, predicted, become available today. Unfortunately, this global negative trend does not depart from Ukraine and our tourists who visit other countries.

Consideration of the main obstacles of tourism development is directly related to the domestic economic problems of country sustainable development. Indeed, for all the complexities and contradictions inherent in the conflict period, the country sustainable development must testify the viability of the idea, its conformity to national interests and priorities.

Research on the problems of tourism development was reflected in the works of V.Azar, O. Amosha, I. Balabanova, M. Birzhakova, D. Vedenina, A. Grischuk, V. Danilchuk, S. Demyanenko, V. Kifiak, M. Kruglov, A. Mazaraki, O. Macari, M. Malskoy, N. Podolchak, J. Poplavskoy, A. Terebukh, T. Tkachenko, V. Tsybukha, V. Fedorchenko, G. Harris, 
A. Chudnovsky, L. Shulgina. However, the problems of tourism sustainable development were considered only occasional in the special literature, both foreign and domestic. These are the works of E. Bogdanov, D. Bowen, R. Braymer, S. Vanhill, D. Gilbert, L. Hryniv, M. Doleshnyi, A. Durovich, I. Zorin, M. Kabushkin, V. Quarterly, O. Kuzmin, K. Coopera, N. Raskina, V. Fedorchenko, D. Fletcher, V. Tsybukha and others.

Therefore, it is necessary to continue actively to develop research on this issue.

Great deals of works are devoted to the study of the theoretical foundations of conflict situations in the world and in Ukraine. It is important to bear in mind that this issue is extremely complex. The essence of this question is being investigated nowadays by different educators and scholars: Averin A., Aziz Kh., Baidyk O., Drakos K., Zavarika G., Zelenko O., Tkachuk L. and others. Most of the authors describe the aspects of the impact of conflict situations on tourism activities.

Thus, the Russian philosopher Averin A.N., developing an expertise in the area of state regulation of demographic and migration processes, implies that migration can be caused by political, economic, social, and spiritual processes. The author has focused on the reasons which include military, national, ethnic, religious conflicts, terrorism, environment and climatic factors [1].

As regards O. Beidyk's conclusions, who argues that the armed conflicts of various sizes and power always have a proportional "effect" on tourism development which reduces the image of the country, destroys the tourist infrastructure and leads to the destruction of the historical and natural heritage, they are not in doubt [2].

The author agrees with L. Tkachuk's opinion who believes that due to the growing political instability the tourism sector faces serious challenges and negative opinions of the situation in the country causes a decline in the tourist flow [13].

The tourist attraction of the region was noted by such scholars as Myshechkin G.V. and Anasova O.S. In particular, they indicate the possibilities of tourism development in Donetsk region. Moreover, they choose those objects that are potentially interesting for tourists and offer such directions of tourism development as industrial tourism, business tourism, ethno-tourism, pilgrimage [11].

However, the state of this issue in the regional aspect, namely in Lugansk and Donetsk regions is not sufficiently well developed [5, 6, 7].

By reason of the armed conflict we lack of new scientific works. It is worth paying attention to O.O. Zelenko's work on the prospects of Lugansk region tourism development in the conditions of military and political instability. The author draws implications that various types of tourism have the right to exist and stresses the necessity to develop tourism in the region, including farm holiday, medical, religious and industrial tourism [8].

Objectives hypothesis. Tourism in the eastern regions of Ukraine has only recently started to form. It was connected with the history of the region development. Historically, the industry has developed in this area and even the public opinion has been formed that tourism can not be developed in the east. But in the pre-conflict period in the eastern regions such tourism types as: rural, curative and health, religious, and industrial started to develop. The tourist industry in the Donbass region suffered the greatest blow after the start of hostilities in 2014. The military conflict has once put forward a promising direction of economic development of the eastern regions of Ukraine on the brink of total disappearance.

All of the above shows the need to study the experience of eliminating the negative effects of conflicts on tourism development, and to develop a strategy for its further development in the Donetsk and Luhansk regions. Consequently, in view of the foregoing, one can speak of the relevance of the topic of the study.

The purpose of the paper is to analyze the state of tourism of eastern Ukraine in the pre-conflict and conflict periods.

Methodology. The research methodology combines the empirical (observation, comparison) and theoretical (systematization and classification) methods of scientific knowledge. During the process of writing the article the historical method and the synthesis of the results also are used. Analytical, deductive, statistical, systemic, comparative-geographic methods of research have been used to analyze the main indicators of tourism development.

Results and discussion. The events of 2014-2018 in Donbass (Donetsk and Luhansk regions) caused the decline of local tourism, which, before the start of hostilities, came out of a crisis and gradually began to gain momentum.

About the gradual development of tourism in the Donetsk region one can find out from the statistical data provided by the central and regional authorities for the collection and processing of statistical data. The main indicators of tourism development in the Donetsk and Luhansk regionss in the pre-conflict period have been shown in tables 1-4.

As can be seen from the data presented, the conflict in the Donbass has not been the only reason for reducing the number of tourist flows in the region. Since 2011 there has been a gradual decline in the number of tourists visiting the Donetsk region.

The main reason for such a decrease is likely to be economic problems and a decline in the standard of living, which negatively affected the tourist visits of the Donetsk region. Even the fact that the capital of the Donetsk region in 2012 hosted key games of the European Football Championship did not save the situation.

The data presented in Table 2 shows that during the key period of the tourist infrastructure, in particular, such a key element as hotels has practically not developed. Moreover, there is a slight decrease in the number of collective accommodation facilities and visitors who stayed in them.

A little bid better in comparison with Donetsk, the main tourist indicators of Luhansk region look like. 
Tourist streams in the Donetsk region on the eve of the conflict [14] (persons)

\begin{tabular}{|c|c|c|c|c|c|}
\hline \multirow[b]{2}{*}{ Years } & \multirow[b]{2}{*}{$\begin{array}{l}\text { Number of tourists } \\
\text { served by subjects } \\
\text { of tourist activity }\end{array}$} & \multicolumn{3}{|c|}{ Of the total number of tourists: } & \multirow[b]{2}{*}{$\begin{array}{c}\text { Number } \\
\text { of excursionists }\end{array}$} \\
\hline & & foreign tourists & $\begin{array}{c}\text { tourists-citizens } \\
\text { of Ukraine who trav- } \\
\text { eled abroad }\end{array}$ & $\begin{array}{c}\text { domestic } \\
\text { tourists }\end{array}$ & \\
\hline 2000 & 77675 & 1646 & 22116 & 53913 & 19898 \\
\hline 2001 & 112912 & 1742 & 25443 & 85727 & 24314 \\
\hline 2002 & 111783 & 3476 & 28569 & 79738 & 20079 \\
\hline 2003 & 158909 & 5137 & 34018 & 119754 & 23587 \\
\hline 2004 & 93739 & 1332 & 34346 & 58061 & 23190 \\
\hline 2005 & 106534 & 1008 & 39880 & 65646 & 26357 \\
\hline 2006 & 125568 & 1263 & 54585 & 69720 & 25520 \\
\hline 2007 & 151924 & 1720 & 64507 & 85697 & 20469 \\
\hline 2008 & 155869 & 3538 & 61760 & 90571 & 21979 \\
\hline 2009 & 123073 & 3137 & 50211 & 69725 & 14831 \\
\hline 2010 & 138833 & 3078 & 60497 & 75258 & 30852 \\
\hline 2011 & 88461 & 1113 & 50486 & 36862 & 7084 \\
\hline 2012 & 90928 & 1109 & 52942 & 36877 & 9459 \\
\hline 2013 & 91011 & 1110 & 53214 & 36901 & 9501 \\
\hline
\end{tabular}

Collective placements in the Donetsk region. in 2011 - 2013 [9]

\begin{tabular}{|c|c|c|c|c|c|c|c|c|c|}
\hline \multirow[b]{3}{*}{ Years } & \multicolumn{3}{|c|}{$\begin{array}{c}\text { Number of collective placement } \\
\text { units, units }\end{array}$} & \multicolumn{3}{|c|}{ Number of seats, units } & \multicolumn{3}{|c|}{ Number of people placed } \\
\hline & \multirow[b]{2}{*}{ Total } & \multicolumn{2}{|c|}{ Including } & \multirow[b]{2}{*}{ Total } & \multicolumn{2}{|c|}{ Including } & \multirow[b]{2}{*}{ Total } & \multicolumn{2}{|c|}{ Including } \\
\hline & & \begin{tabular}{|c|} 
hotels and \\
similar \\
accommo- \\
dation \\
facilities
\end{tabular} & $\begin{array}{c}\text { specialized } \\
\text { placement } \\
\text { tools }\end{array}$ & & \begin{tabular}{|c|} 
hotels and \\
similar \\
accom- \\
modation \\
facilities
\end{tabular} & $\begin{array}{c}\text { specialized } \\
\text { placement } \\
\text { tools }\end{array}$ & & $\begin{array}{c}\text { hotels and } \\
\text { similar } \\
\text { accom- } \\
\text { modation } \\
\text { facilities }\end{array}$ & $\begin{array}{c}\text { specialized } \\
\text { placement } \\
\text { tools }\end{array}$ \\
\hline 2011 & 494 & 140 & 354 & 51033 & 6351 & 44682 & 410028 & 191548 & 218480 \\
\hline 2012 & 483 & 135 & 348 & 51066 & 7577 & 43489 & 471705 & 238745 & 232960 \\
\hline 2013 & 458 & 139 & 319 & 48859 & 7570 & 41289 & 454175 & 233969 & 220206 \\
\hline
\end{tabular}

Tourist streams in Lugansk region in 2000 - 2013 [14]

Table 3 (persons)

\begin{tabular}{|c|c|c|c|c|c|}
\hline \multirow[t]{2}{*}{ Years } & \multirow{2}{*}{$\begin{array}{l}\text { The number of tour- } \\
\text { ists served by } \\
\text { the subjects of tourist } \\
\text { activity of Ukraine - } \\
\text { total }\end{array}$} & \multicolumn{3}{|c|}{ Of the total number of tourists: } & \multirow[b]{2}{*}{$\begin{array}{c}\text { Number } \\
\text { of excursionists }\end{array}$} \\
\hline & & foreign tourists & $\begin{array}{l}\text { tourists-citizens } \\
\text { of Ukraine who } \\
\text { traveled abroad }\end{array}$ & domestic tourists & \\
\hline 2000 & 23710 & 476 & 1931 & 21303 & 9487 \\
\hline 2001 & 28788 & 439 & 2852 & 25497 & 13342 \\
\hline 2002 & 41335 & 515 & 3714 & 37106 & 23615 \\
\hline 2003 & 42126 & 850 & 4655 & 36621 & 26215 \\
\hline 2004 & 41662 & 603 & 5147 & 35912 & 28639 \\
\hline 2005 & 48898 & 17 & 6913 & 41968 & 34889 \\
\hline 2006 & 50881 & 162 & 10761 & 39958 & 30993 \\
\hline 2007 & 59096 & 158 & 14088 & 44850 & 39984 \\
\hline 2008 & 53279 & 126 & 15487 & 37666 & 21022 \\
\hline 2009 & 44341 & 163 & 11584 & 32594 & 29940 \\
\hline 2010 & 35880 & 162 & 13304 & 22414 & 20062 \\
\hline 2011 & 15558 & 94 & 9284 & 6180 & 1854 \\
\hline 2012 & 21981 & 120 & 12231 & 9630 & 6839 \\
\hline 2013 & 22015 & 122 & 12300 & 9603 & 6741 \\
\hline
\end{tabular}


Collective means of placement in Luhansk region in 2011-2013 [10]

\begin{tabular}{|c|c|c|c|c|c|c|c|c|c|}
\hline \multirow[b]{3}{*}{ Years } & \multicolumn{3}{|c|}{$\begin{array}{c}\text { Number of collective placement } \\
\text { units, units }\end{array}$} & \multicolumn{3}{|c|}{ Number of seats, units } & \multicolumn{3}{|c|}{ Number of people placed } \\
\hline & \multirow[b]{2}{*}{ Total } & \multicolumn{2}{|c|}{ Including } & \multirow[b]{2}{*}{ Total } & \multicolumn{2}{|c|}{ Including } & \multirow[b]{2}{*}{ Total } & \multicolumn{2}{|c|}{ Including } \\
\hline & & $\begin{array}{c}\text { hotels and } \\
\text { similar ac- } \\
\text { commo- } \\
\text { dation fa- } \\
\text { cilities }\end{array}$ & $\begin{array}{l}\text { specialized } \\
\text { placement } \\
\text { tools }\end{array}$ & & $\begin{array}{c}\text { hotels and } \\
\text { similar } \\
\text { accommo- } \\
\text { dation fa- } \\
\text { cilities }\end{array}$ & $\begin{array}{c}\text { specialized } \\
\text { placement } \\
\text { tools }\end{array}$ & & $\begin{array}{c}\text { hotels and } \\
\text { similar ac- } \\
\text { commo- } \\
\text { dation fa- } \\
\text { cilities }\end{array}$ & $\begin{array}{c}\text { specialized } \\
\text { placement } \\
\text { tools }\end{array}$ \\
\hline 2011 & 112 & 60 & 52 & 7123 & 2859 & 4264 & 142399 & 95943 & 46456 \\
\hline 2012 & 109 & 45 & 64 & 6195 & 1749 & 4446 & 141113 & 90788 & 50325 \\
\hline 2013 & 105 & 51 & 54 & 5741 & 2078 & 3663 & 145289 & 101945 & 43344 \\
\hline
\end{tabular}

At the beginning of the second decade of the XXI century there was a marked decline in the overall tourist flow, however, in 2012 the tourist sector of Lugansk region managed to return some lost positions.

Of the data presented in Table 4, it can be seen that the hotel sector in the Luhansk region has almost not developed. Significant reduction of collective accommodations in 2013 compared with 2011 is observed.

For a long time, the territory of Donetsk and Lugansk regions, whose economic potential was dominated by a strong industrial base, was not considered as attractive tourist areas. However, at the beginning of the twenty-first century a number of leading scientists and experts talked about the possibility of developing the tourist potential of the Donbas region. In particular, the tourist attractiveness of the region was noted by such scholars as GV Myshechkin and O.S. Anosova In the article devoted to the analysis of the possibilities of development of the tourism industry in the Donbass, they note: "Donbass (meaning Donetsk and Lugansk regions) has significant opportunities for tourism development: outstanding geological, hydrological and botanical monuments of nature, rich historical past of the region, numerous historical and cultural monuments, resort complexes, dozens of unique productions, etc. Modern Donbass is the most densely populated region of Ukraine. All this can not but attract the attention of domestic and foreign tourists "[11].

Then they point out to those objects that are potentially interesting for tourists. According to their information, in 2012 in Donetsk region was concentrated 16\% of sanitary-resort establishments of Ukraine. Within the region there is $110 \mathrm{~km}$ of coast of the Sea of Azov with unique sandy beaches, at the state level there are 113 protected areas, including two national parks ("Holy Mountains", "Meotida"), Khomutovsky step, "Stone" reserve Graves", lakes of Slovyansk district of karst origin, Krasnolimansky forest with unique climate, regional landscape parks (RLP)"KlebanBik","Zuevsky","Polovets steppe","Donetsk ridge", landscape reserve" Bestash "etc. [11].

In addition, the Donbass has the potential to develop such areas of tourism as: industrial tourism, business tourism, ethno-tourism, pilgrimage. Also in the Donetsk region there were public organizations of national minorities: the Greek diaspora in the Priazovye (Mariupol city), the German diaspora in the Telmanovsky district, the Jewish community in Donetsk, etc. [11].
Extremely promising for Donbass is the development of industrial tourism. A peculiar tourist attraction card of the region was the Artemivsk Sparkling Winery, the salt mines of Soledar city.

"Green tourism" is also perspective. In Luhansk region, before the beginning of 2013, several directions on the development of this type of tourism were introduced at once, namely : green, industrial, recreational, cognitive, sports, etc. Despite the fact that the Lugansk region belongs to the group of industrial regions, it had every chance, despite this fact, to reposition itself on the national market of tourist services as a tourist-attractive region [11].

Several significant tourist objects are located in the Luhansk region, in particular, 7 territories and objects of the nature reserve fund, among them are such natural monuments as Aidar Terrace and Congresses Yar, Lugansk Nature Reserve, 6 parks - memorials of the garden park art, 13 wildlife sanctuaries, 48 nature monuments, 14 nature reserves [7].

Green tourism received a significant spread on the eve of the conflict in Lugansk region. In 2007 the Luhansk Regional Branch of the Union for the Promotion of Rural Green Tourism Development in Ukraine was founded. In two years, the division of the union numbered about 10 estates, the number of which grew from year to year [7].

In addition, the work on inventory of attractive tourist facilities and the entire tourist infrastructure was intensified, work was carried out on the certification of rural homesteads, tourist guidebooks "Lugansk region the dawn of Ukraine", "Magic Lugansk region. Holidays in the countryside "," Routes in Lugansk "[8].

Thanks to the enthusiasts of tourism industry development in the eastern regions of Ukraine, in the first decade of the XXI century Donbass Territory began to gradually attract tourists. Thus, according to Forbes magazine, in 2011, according to the level of tourist attractiveness, Donetsk ranked 9th, Lugansk - 40th, Artemivsk - 44th, Mariupol - 50th. In 2012, the results were somewhat better: Donetsk - 3rd place, Artemivsk 32nd, Lugansk - 42nd, Mariupol - 46th. All this points to positive developments, but to a significant improvement in the image of the region was still far away [8].

The tourist potential and attractiveness of the East of Ukraine for travelers increased significantly after the holding of separate matches of the final part of the European Football Championship in 2012. Within the frame- 
work of the preparation for this event, large-scale infrastructure projects have been implemented, new cultural institutions have appeared, which became a tourist "highlight the region ". Similar changes took place not only in Donetsk, where international football meetings were held on the new stadium, but also in other cities of Donbass. In particular, on June 2, 2012, in honor of the championship, a museum dedicated to the outstanding Brazilian football player Pele [8] was officially opened in Luhansk.

In general, according to the results of the tourist enterprises of the region in 2013, Eastern Ukraine was visited by 170,39 thousand people, which is on $1,5 \%$ more compared with 2012. Domestic tourism (by number of visitors) by the results of 2013 (comparatively with 2012) increased by $6 \%$ and amounted to 70.7 thousand people. The volume of tourist services provided for the relevant period has increased by $6,4 \%$ and amounted to 581,7 million UAH. In the budget of the Donetsk region for the provision of tourist services in 201312.9 million UAH were received [8].
The conflict in the Donbass 2014-2018 was one of the main reasons for deepening the social and economic crisis in Ukraine. It affected all the Ukrainian economy, and tourism was no exception. Over the past four years there has been a decline in indicators in many industries: the number of tourists, the number of tourist facilities, the total tourist flow.

In particular, the state statistics authorities recorded a decrease in the number of tourists who traveled to Ukraine. This trend has been reflected in Table 5.

Consequently, according to official statistics posted on the website of the State Statistics Service, it can be seen that over the last two military years, the number of foreign tourists, compared with 2013, has more than doubled. The most foreigners who arrived in Ukraine in 2016-2017 were from Moldova, Belarus, Russia, Hungary, Poland, Romania, Slovakia, Turkey, Israel, Germany.

Other indicators of arriving foreign citizens to Ukraine, in particular, cultural and sports exchanges, have been significantly decreased (Table 6-7).

Table 5

Entry of foreign citizens-tourists to the territory of Ukraine during the conflict [14]

\begin{tabular}{|c|c|c|c|}
\hline $\mathbf{2 0 1 3}$ & $\mathbf{2 0 1 4}$ & $\mathbf{2 0 1 5}$ & $\mathbf{2 0 1 6}$ \\
\hline 488496 & 146804 & 137906 & 126845 \\
\hline
\end{tabular}

Table 6

Entrance of foreign citizens to the territory of Ukraine for sports and tourism exchange in 2013-2015 [14]

\begin{tabular}{|c|c|c|}
\hline $\mathbf{2 0 1 3}$ & $\mathbf{2 0 1 4}$ & $\mathbf{2 0 1 5}$ \\
\hline 5841872 & 2814021 & 720253 \\
\hline
\end{tabular}

Table 7

Tourist streams in Ukraine for 2013 - 2016 [14]

\begin{tabular}{|l|c|c|c|c|c|c|c|}
\hline Years & $\begin{array}{c}\text { Number of } \\
\text { citizens of } \\
\text { Ukraine } \\
\text { who trav- } \\
\text { eled abroad }\end{array}$ & $\begin{array}{c}\text { Number of } \\
\text { foreign citi- } \\
\text { zens who } \\
\text { visited } \\
\text { Ukraine }\end{array}$ & $\begin{array}{c}\text { Number of } \\
\text { tourists served } \\
\text { by subjects of } \\
\text { tourist activity } \\
\text { Of Ukraine }\end{array}$ & $\begin{array}{c}\text { Foreign } \\
\text { tourists }\end{array}$ & $\begin{array}{c}\text { Tourists- } \\
\text { citizens of } \\
\text { Ukraine who } \\
\text { traveled } \\
\text { abroad }\end{array}$ & $\begin{array}{c}\text { Domestic } \\
\text { tourists }\end{array}$ & $\begin{array}{c}\text { Number of } \\
\text { excursionists }\end{array}$ \\
\hline $\mathbf{2 0 1 3}$ & 23761287 & 24671227 & 3454316 & 232311 & 2519390 & 702615 & 657924 \\
\hline $\mathbf{2 0 1 4}$ & 22437671 & 12711507 & 2425089 & 17070 & 2085273 & 322746 & 1174702 \\
\hline $\mathbf{2 0 1 5}$ & 23141646 & 12428286 & 2019576 & 15159 & 1647390 & 357027 & 125471 \\
\hline $\mathbf{2 0 1 6}$ & 23257145 & 12578165 & 2009478 & 14975 & 16168178 & 364142 & 134048 \\
\hline
\end{tabular}

The given statistical materials show a very noticeable decrease in connection with the conflict of the general tourist flow in all directions. This applies to both external and internal tourism.

The conflict between 2014 and 2018 negatively affected the development of Ukraine's tourist infrastructure. In particular, there is a decrease in the number of sanatoriums and health facilities (Table 8).

The reduction in the number of tourist facilities in the period from 2013 to 2014 was due to the fact that a significant number of them was in the zone of Russian occupation in the Crimea, or in the territory of the ATO in the Donets Basin. A further decrease in the number of sanatoriums and health facilities in 2016 was caused by the deepening economic crisis.

Also, according to official statistics, for the last three years the decline in the profitability of the tourism industry, as shown in Figure 1, has been recorded.

Thus, in connection with the beginning of the ATO, there is a significant decline of the tourism industry in the area of hostilities. This can be argued, based on statistics provided on the website of the Main Department of Statistics in Donetsk Region. In particular, the data presented here indicate a reduction in tourist flows (Table 9).

The given data shows a catastrophic reduction of tourist flows in the Donetsk region. The number of for- 
eign tourists visiting the region in the first years of the conflict decreased by almost ten times, the number of domestic tourists for the same period also decreased by five - six times.

Sanatorium and spa facilities in 2013 - 2016 [3]

\begin{tabular}{|c|c|c|c|c|c|}
\hline Years & $\begin{array}{c}\text { Sanatoriums and } \\
\text { boarding houses } \\
\text { with treatment }\end{array}$ & $\begin{array}{c}\text { Sanatorium- } \\
\text { preventorium }\end{array}$ & $\begin{array}{c}\text { Houses and } \\
\text { holiday resorts }\end{array}$ & $\begin{array}{c}\text { Camps and other } \\
\text { recreation facili- } \\
\text { ties }\end{array}$ & $\begin{array}{c}\text { Children's health and } \\
\text { recreation facilities }\end{array}$ \\
\hline $\mathbf{2 0 1 3}$ & 477 & 165 & 271 & 1916 & 18549 \\
\hline $\mathbf{2 0 1 4}$ & 320 & 118 & 90 & 1400 & 13977 \\
\hline $\mathbf{2 0 1 5}$ & 309 & 79 & 76 & 1399 & 9743 \\
\hline $\mathbf{2 0 1 6}$ & 301 & 77 & 71 & 13979 & 8945 \\
\hline
\end{tabular}

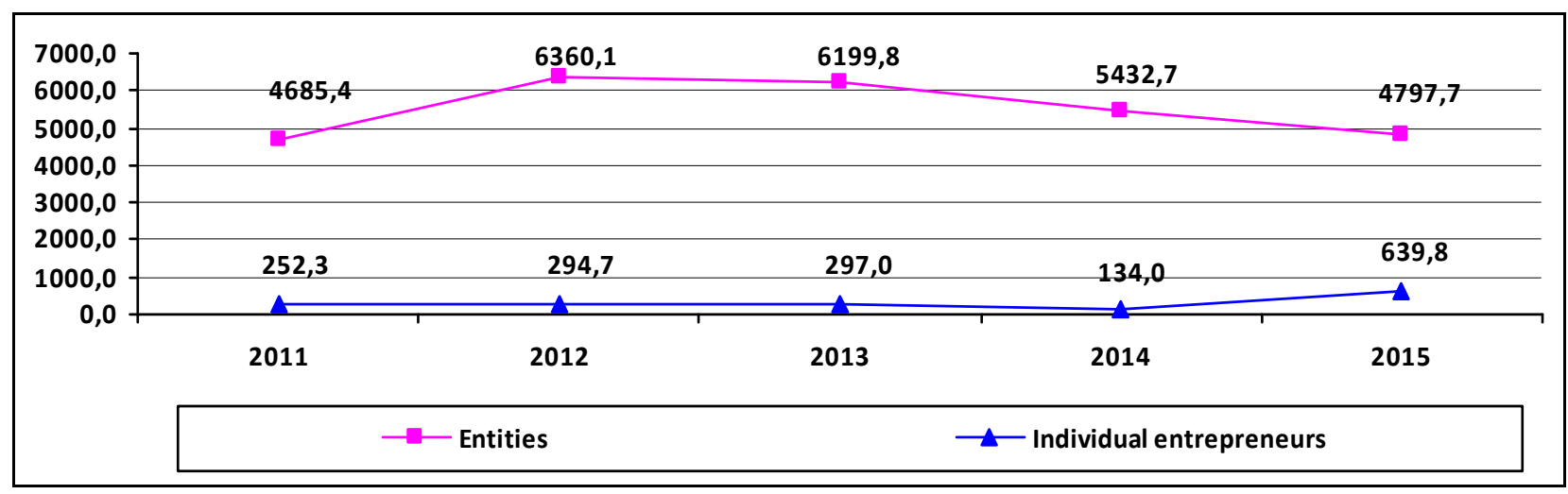

Fig. 1. Income from provision of tourist services, mln.UAH [14]

Tourist streams in the Donetsk region in 2013-2016 [14]

\begin{tabular}{|c|c|c|c|c|c|}
\hline Years & $\begin{array}{c}\text { The number of tour- } \\
\text { ists served by } \\
\text { the subjects of tour- } \\
\text { ist activity of } \\
\text { Ukraine- total }\end{array}$ & $\begin{array}{c}\text { Foreign } \\
\text { tourists }\end{array}$ & $\begin{array}{c}\text { Tourists-citizens } \\
\text { of Ukraine who } \\
\text { traveled abroad }\end{array}$ & Domestic tourists & $\begin{array}{c}\text { Number } \\
\text { of excursionists }\end{array}$ \\
\hline $\mathbf{2 0 1 3}$ & 113917 & 1222 & 80426 & 32269 & 10005 \\
\hline $\mathbf{2 0 1 4}$ & 14834 & 147 & 6767 & 7920 & 630 \\
\hline $\mathbf{2 0 1 5}$ & 13978 & 149 & 6015 & 7154 & 590 \\
\hline $\mathbf{2 0 1 6}$ & 13478 & 154 & 5075 & 6785 & 584 \\
\hline
\end{tabular}

During the years of the conflict, the number of objects of tourist infrastructure in the Donetsk region has been significantly decreased. This tendency is clearly traced in Table 10 below. The given data will show that in the conditions of the conflict the number of tourist objects in the Donetsk region has been decreased by five - six times. Some of the collective facilities were in the occupation zone, part of it was destroyed, part of it was closed due to a significant reduction of the tourist flow to the region.

Even more reduction of tourist flows due to the beginning of the conflict is observed in the Lugansk region (Table 11).

Children's recreation and holiday facilities in the Donetsk region in 2013 - 2016 [3]

\begin{tabular}{|c|c|c|c|c|}
\hline \multirow{2}{*}{ Years } & \multicolumn{2}{|c|}{ Number of institutions, units } & \multicolumn{2}{c|}{ They have seats, units } \\
\cline { 2 - 5 } & Total & $\begin{array}{c}\text { including health } \\
\text { improvement facilities }\end{array}$ & Total & $\begin{array}{c}\text { including health } \\
\text { improvement facilities }\end{array}$ \\
\hline $\mathbf{2 0 1 3}$ & 1093 & 61 & 19107 & 19107 \\
\hline $\mathbf{2 0 1 4}$ & 590 & 25 & 9200 & 9200 \\
\hline $\mathbf{2 0 1 5}$ & 324 & 18 & 5800 & 5640 \\
\hline $\mathbf{2 0 1 6}$ & 275 & 15 & 4571 & 4821 \\
\hline
\end{tabular}


Tourist streams in the Luhansk region in 2013 - 2016 [14]

\begin{tabular}{|c|c|c|c|c|c|}
\hline Years & $\begin{array}{c}\text { The number of } \\
\text { tourists served by } \\
\text { the subjects of } \\
\text { tourist activity of } \\
\text { Ukraine - total }\end{array}$ & Foreign tourists & $\begin{array}{c}\text { Tourists-citizens } \\
\text { of Ukraine who } \\
\text { traveled abroad }\end{array}$ & Domestic tourists & $\begin{array}{c}\text { Number } \\
\text { of excursionists }\end{array}$ \\
\hline $\mathbf{2 0 1 3}$ & 34699 & 33 & 21709 & 12957 & 6684 \\
\hline $\mathbf{2 0 1 4}$ & 791 & 2 & 762 & 27 & - \\
\hline $\mathbf{2 0 1 5}$ & 939 & - & 872 & 67 & - \\
\hline $\mathbf{2 0 1 6}$ & 1896 & - & 1814 & 82 & - \\
\hline
\end{tabular}

So, we see that the tourist sector of the Lugansk region has suffered the most from the conflict. The small flow of foreign tourists that had been before, in 2016 was almost completely interrupted. However, the largest decline was the number of domestic tourists, who, according to statistics, visited the region quite actively for the last pre-war year.

This is also due to the fact that in 2015 , by the orders of the head of the regional state administration - the head of the military-civilian administration from 07.04.2015 № 127 and from 05.2015 to 511 were forbidden to conduct tourist trips, excursions and campaigns in the region. By order of the head of the regional state administration - from 09.08.2016 № 464 the ban on tourist trips, excursions and hikes in the region was canceled, except for the Stanichno-Luhansk, Novoaydarsky and Popasnyansky districts located along the line of col- lision between the checkpoints of the first and second boundaries.

In connection with the beginning of hostilities in the Luhansk region, the number of tourist objects of different destination were significantly decreased. In particular, the number of children's recreation and holiday facilities were decreased significantly (Table 12).

The number of other tourist objects were also significantly decreased (Table 13). The catastrophic reduction of the tourist flow could not but negatively affect the development of tourism infrastructure. The given data shows a significant reduction of hotels, and other means of collective accommodation.

Thus, we can state that the events of 2014-2018, connected with the conflict led to the crisis of the tourist industry of the Donbas.

Table 12

Children's recreation and holiday facilities of the Luhansk region in 2013 - 2015 [14]

\begin{tabular}{|c|c|c|c|c|c|c|}
\hline \multirow{2}{*}{ Years } & \multicolumn{2}{|c|}{ Number of institutions, units } & \multicolumn{2}{|c|}{ They have seats, units } & \multicolumn{2}{c|}{$\begin{array}{c}\text { The number of children who were in } \\
\text { institutions, persons }\end{array}$} \\
\cline { 2 - 7 } & Total & $\begin{array}{c}\text { including health } \\
\text { improvement } \\
\text { facilities }\end{array}$ & Total & $\begin{array}{c}\text { including health } \\
\text { improvement } \\
\text { facilities }\end{array}$ & Total & $\begin{array}{c}\text { including health } \\
\text { improvement facilities }\end{array}$ \\
\hline $\mathbf{2 0 1 3}$ & 788 & 36 & 9720 & 9720 & 53558 & 17036 \\
\hline $\mathbf{2 0 1 4}$ & 193 & 2 & 225 & 225 & 9836 & 287 \\
\hline $\mathbf{2 0 1 5}$ & 167 & 5 & 1695 & 1695 & 9398 & 2429 \\
\hline
\end{tabular}

Table 13

Collective means of placement Lugansk region in 2013 and 2014 [10]

\begin{tabular}{|c|c|c|c|c|c|c|c|c|c|}
\hline \multirow[b]{3}{*}{ Years } & \multicolumn{3}{|c|}{$\begin{array}{c}\text { Number of collective placement } \\
\text { units, units }\end{array}$} & \multicolumn{3}{|c|}{ Number of seats, units } & \multicolumn{3}{|c|}{ Number of people placed } \\
\hline & \multirow[b]{2}{*}{ Total } & \multicolumn{2}{|c|}{ Including } & \multirow[t]{2}{*}{ Total } & \multicolumn{2}{|c|}{ Including } & \multirow[t]{2}{*}{ Total } & \multicolumn{2}{|c|}{ including } \\
\hline & & $\begin{array}{l}\text { hotels and } \\
\text { similar } \\
\text { accommo- } \\
\text { dation } \\
\text { facilities }\end{array}$ & $\begin{array}{c}\text { specialized } \\
\text { placement } \\
\text { means }\end{array}$ & & $\begin{array}{l}\text { hotels and } \\
\text { similar ac- } \\
\text { commo- } \\
\text { dation facili- } \\
\text { ties }\end{array}$ & $\begin{array}{c}\text { specialized } \\
\text { placement } \\
\text { means }\end{array}$ & & $\begin{array}{c}\text { hotels and } \\
\text { similar ac- } \\
\text { commo- } \\
\text { dation fa- } \\
\text { cilities }\end{array}$ & $\begin{array}{c}\text { specialized } \\
\text { placement } \\
\text { means }\end{array}$ \\
\hline 2013 & 105 & 51 & 54 & 5741 & 2078 & 3663 & 145289 & 101945 & 43344 \\
\hline 2014 & 21 & 13 & 8 & 1682 & 585 & 1097 & 9715 & 5195 & 4520 \\
\hline
\end{tabular}

Many of the sites that previously caused interest in tourists are in the occupied zone or in the danger zone. So, during the conflict, in the Donetsk region, 21 institutions of cultural and tourist sphere were damaged and losses were incurred for 18353379 thousand UAH. Among them, and the Kleban Bick Landscape Park, which is located between 2-d and 3-d lines of defense (part of the park has been mined); during the construc- 
tion of defensive buildings in the Volodarsky district, mounds were damaged [7].

The situation is also not better in the Luhansk region. Like O. Zelenko noted, pondering of the consequences of the military conflict for the development of tourism in Lugansk region: "Today, from 18 regions of Lugansk region, its tourist and recreational resources can offer only 10 districts, namely: Bilovodsky, Bilokurakinsky, Kreminsky, Markovsky, Milovsky, Novoaydarsky, Novopskovsky, Svatovsky, Starobilivsky and Troitsky districts. Two more districts: Stanichno-Lugansky and Popasniansky are although under the control of the Ukrainian authorities, but close proximity to the "line of collision" of the warring parties, and now the inadequate condition of the existing housing and communal infrastructure does not allow them to be considered even as potentially attractive territories for development tourism in the near future"[8].

In addition, with the onset of the conflict, most of the green tourism objects located in different areas were forced to close [8].

The Lugansk natural reserve, which is still in the zone of active armed confrontation, has suffered from the conflict. Even those regions of the Luhansk region, where there were no military actions, remain unattractive for tourists and travelers. First of all, they are located in the area of anti-terrorist operation, on the territory of which all important routes are blocked by block posts and the passport regime is in force. In addition, much of the local infrastructure, in particular, roads are in poor condition, due to the fact that heavy military equipment has long been moving along them. The lack of effective infrastructure was a typical problem of the eastern regions of Ukraine before the start of the Anti-Terrorist Operation. In 2013, the international organization "Fredrich Ebert Stiftung" conducted a study of the state of roads in various regions of Ukraine. According to expert opinions, the infrastructure of Luhansk region is characterized by "outdated rolling stock of passenger transport; incompatibility of the transport infrastructure with modern requirements; low throughput of national roads; loss-making of transport due to the provision of numerous travel privileges under conditions of insufficient budget financing; heavy traffic in the streets of the regional center and low traffic safety on the roads.

Distribution of tourists serviced by tour operators and travel agents according to the trip purpose of and types of tourism in 2016 by region, persons [14]

\begin{tabular}{|c|c|c|c|c|c|c|c|c|}
\hline & \multirow[b]{2}{*}{$\begin{array}{c}\text { Served } \\
\text { tourists, all }\end{array}$} & \multicolumn{6}{|c|}{ Including the purpose of travel } & \multirow{2}{*}{$\begin{array}{l}\text { Of these, } \\
\text { children } \\
\text { are } 0-17 \\
\text { years old }\end{array}$} \\
\hline & & $\begin{array}{c}\text { service, } \\
\text { business, } \\
\text { training }\end{array}$ & leisure, rest & treatment & sport & special & others & \\
\hline Ukraine & 2250107 & 176230 & 1902900 & 79412 & 2982 & 768 & 87815 & 199956 \\
\hline \multicolumn{9}{|l|}{ Regions } \\
\hline Vinnitsa & 11348 & 5 & 11321 & 22 & - & - & - & 1681 \\
\hline Volyn & 16525 & 6 & 15648 & 871 & - & - & - & 1448 \\
\hline Dnipropetrovsk & 24296 & 207 & 23037 & 918 & 134 & - & - & 4143 \\
\hline Donetsk & 9753 & 69 & 9240 & 56 & 7 & - & 381 & 1550 \\
\hline Zhytomyr & 2597 & 2 & 2595 & - & - & - & - & 398 \\
\hline Zacarpathiy & 6705 & 76 & 6532 & 12 & - & - & 85 & 1267 \\
\hline Zaporozhye & 21016 & 278 & 19789 & 949 & - & - & - & 2458 \\
\hline Ivano-Frankivsk & 74919 & - & 72273 & 334 & - & - & 2312 & 3587 \\
\hline Kyiv region & 11001 & 6 & 10815 & 151 & 7 & 22 & - & 1763 \\
\hline Kirovograd region & 2181 & 20 & 2137 & 24 & - & - & - & 315 \\
\hline Luhansk & 577 & 4 & 535 & 38 & - & - & - & 40 \\
\hline Lviv & 138048 & 658 & 74267 & 61645 & 406 & 127 & 945 & 9291 \\
\hline Mikolaiv & 5575 & 2 & 5561 & 10 & 2 & - & - & 610 \\
\hline Odesa & 43355 & 12721 & 30002 & 35 & 74 & 276 & 247 & 2854 \\
\hline Poltava & 3383 & 123 & 3076 & 122 & 22 & 40 & - & 689 \\
\hline Rivne & 4266 & 3 & 4247 & 16 & - & - & - & 595 \\
\hline Sumy & 5665 & 1559 & 3862 & 27 & - & - & 217 & 283 \\
\hline Ternopol & 2934 & 41 & 2764 & - & 129 & - & - & 914 \\
\hline Kharkiv & 19122 & 89 & 18529 & 455 & 12 & 37 & - & 2386 \\
\hline Kherson & 4647 & 2 & 2987 & 1646 & - & - & 12 & 544 \\
\hline Khmelnitsky & 9319 & 10 & 8782 & 24 & - & - & 503 & 1088 \\
\hline Cherkassy & 2624 & 1 & 2542 & 63 & - & - & 18 & 566 \\
\hline Chernivtsi & 11731 & 185 & 11309 & 29 & 51 & 1 & 156 & 1275 \\
\hline Chernihiv & 3869 & 4 & 3861 & 4 & - & - & - & 340 \\
\hline Kyiv & 1814651 & 160159 & 1557189 & 11961 & 2138 & 265 & 82939 & 159871 \\
\hline
\end{tabular}

${ }^{I}$ Excluding the temporarily occupied territory of the Crimea Autonomous Republic, the city of Sevastopol and parts of ATO zone. 
First of all, there is a lack of a clearly formulated strategy for tourism development, its main directions have not been defined.

The legislative framework, including the legal mechanisms for the transfer of objects to private entrepreneurs, which they are ready to turn into popular tourist establishments, needs to be improved. It is also necessary to develop the principles of exempting such objects from excessive tax pressure, at least at the stage of formation.

The intensification of efforts to promote tourism opportunities in Luhansk and Donetsk regions, both at the local and state level is not less important.However, this is impossible without creating a region brand, which will show potential tourists, with what, they should become familiar first of all, if they visit the eastern regions of Ukraine.

And finally, the key issue that can not be solved without active state support is the development of the Donbas infrastructure, which had been in decline before the war. It has always been a factor that frightened potential tourists from visiting the region.

The analysis of the impact of the conflict on tourism in the eastern regions could not but be entirely frightened on the country, so we propose to stay on this issue as well.

According to the world rating of the foreign tourists number, compared to the data of 2013, Ukraine lost half of the position dropped from 14 to $25^{\text {th }}$ place, and reduced the number of visitors from 24671 thousand people to 12721 thousand people. According to the State Statistics Service in 2016, the regions of Odessa, Kyiv, Lviv and Ivano-Frankivsk are tourist-developed regions as it was before. Thus, 43355 tourists were served in the Odessa region, in Kyiv region and Kyiv - 1825652, in Lviv - 138048, and in Ivano-Frankivsk regions - 74919. Totally in Ukraine it was serviced 2250997 people [14] (Table 14).

Kherson, Odesa and Mykolayiv regions enjoy popularity. But, there the service does not correspond to the value of process that grew up in times after the occupation of the Crimean peninsula. Although in the southern part of the country last year rested about 3 million people. In other directions, such as the Carpathians, Chernobyl and Pripyat, and others - the number of tourists increased by $20 \%$.

Israel is also in a state of war constantly and it does not prevent the country from developing economies and tourism. We really need to take the experience of this country. Ukraine is a brand, its image needs to be developed and promoted, no matter what. It is also useful for public relations and for the economy of our country.

So, it can be noted that the favorable geographical location, attractive tourist resources, the presence of sights, developed tourist infrastructure and skilled labor resources do not guarantee the successful development of tourism. In fact, a paradoxical situation arises when countries with less attractive natural and culturalhistorical backgrounds than Ukraine have a significantly higher ranking of tourist attractiveness in the world market for tourist services. It is a fact that in the conditions of globalization, in order to increase the rating of tourist attraction, it is necessary not only to monitor the indicators of tourism development, but to use actively the levers of geo-differentiation and positioning of the tourist space to reflect the distinctive features of national tourist product offer.

Conclusions, recommendations and future research. The analysis of statistical data allows us to assert that in the pre-conflict period, attention was not paid to tourism in the region. Tourism in Lugansk and Donetsk regions was not perceived as a strategic sphere, the development of which would contribute to the revitalization of the social situation and economic growth. This was due to its low growth rate, which was manifested in abandoned infrastructure, relatively small number of hotels, lack of legislative guarantees of the activities of local tour operators. As a result, the number of tourists visiting the region during the pre-conflict period was relatively small compared with other regions. The conflict between 2014 and 2018 only deepened the existing problems and contributed to the emergence of new ones.

Today, Ukraine needs significant investment in tourism development, first of all, in tourism infrastructure, which is one of the main reasons preventing the growth of the tourist sector due to its obsolete nature and the inability to meet the needs of potential consumers.

The current state of tourism of the east of Ukraine can be defined as complex and controversial, as there are serious social and geographical problems of the theoretical and applied nature. Social and economic processes are becoming more unpredictable, which leaves its imprint on the development of tourism. Significant changes of the political map of the world, structural changes in the international economy, the finding of Ukraine in a state of conflict led to the emergence of new social geographical features of the development of tourism in the east of Ukraine.

\section{References:}

1. Averyn, A.N. (2017). Gosudarstvennoe regulirovanie demograficheskikh i migratsionnykh protsessov v Rossiyskoy federatsii [State regulation of demographic and migration processes in the Russian Federation]. M.: LLC Prospekt [in Russian].

2. Beidyk, O.O., Koroma, N.S., Syrovets, S.Yu. (2016). Svitovyi turystychnyi rukh: stan, tendentsii ta perspektyvy rozvytku v konteksti suchasnykh geopolitychnykh zahroz [World Traveler Movement: Status, Trends and Development Prospects in the Context of Contemporary Geopolitical Threats]. Geography and Tourism: Sciences. ed. I ed. count Lyubitseva O.O. and others. - K.: Alpha-PIC, 37, 3-15 [in Ukrainian].

3. Dytyachi zaklady ozdorovlennya ta vidpochynku v Donetskiy oblasti u 2013, 2014, 2015 rr. [Children's recreation and recreation facilities in the Donetsk region in 2013, 2014, 2015]. The Main Department of Statistics in Donetsk Region. Retrieved from http://www.donetskstat.gov.ua/statinform1/tourism3.php [in Ukrainian]. 
4. Dytyachi zaklady ozdorovlennya ta vidpochynku Luhanskoi oblasti v 2013, 2014, 2015 rr. [Children's recreation and recreation facilities of Luhansk region in 2013, 2014, 2015] The Main Department of Statistics in Lugansk Region. Retrieved from http://lg.ukrstat.gov.ua/sinf/turizm/turizm.php.htm [in Ukrainian].

5. Zavarika, H.M. (2015). Rozvytok krain v postkonfliktnykh sytuatsiyakh [Developing countries in post-conflict situations]. Galician Economic Herald. Ternopil, 2 (49), 106-113 [in Ukrainian].

6. Zavarika, H.M. (2016). Teoretychne obhruntuvannya konfliktnoi modeli suspilstva [Theoretical justification of the conflict model of society]. Geography and Tourism: Science. ed. / ed. count Lyubitseva O.O. and others. - K.: Alfa-PIC, 37, 189-198 [in Ukrainian].

7. Zelenko, O.O., Zavarika, H.M. (2017). Suspilno-geografichni aspekty rozvytku turyzmu «kraynioho» skhodu Ukrainy [Socio-geographical aspects of tourism development of the «extreme» East of Ukraine]. I All-Ukrainian Distance Scientific and Practical Conference of Young Scientists «Tourism of Modern Issues and Prospects», Ternopil, FOP Osadzha Yu.V. [in Ukrainian].

8. Zelenko, O.O. (2015). Perspektyvy rozvytku turyzmu Luhanshchyny v umovakh voyenno-politychnoi nestabilnosti [Prospects for tourism development in Lugansk region in conditions of military-political instability]. Scientific herald of Mukachevo State University. Economics series, 2(4), 2, 138-143 [in Ukrainian].

9. Kolektyvni zasoby rozmishchuvannya v Donetskii oblasti za 2013, 2014 rr. [Collective placements in the Donetsk region for 2013, 2014] The Main Department of Statistics in Donetsk Region. Retrieved from http://www.donetskstat.gov.ua/statinform1/tourism3.php [in Ukrainian].

10. Kolektyvni zasoby rozmishchuvannya Luhanskoi oblasti u 2013 ta 2014 rr. [Collective means of placement of Luhansk region in 2013 and 2014] The Main Department of Statistics in Lugansk Region. Retrieved from http://lg.ukrstat.gov.ua/sinf/turizm/turizm.php.htm [in Ukrainian].

11. Myshechkin, H.V., Anosova, O.S. (2013). Turystsko-rekreatsiynyi potentsial Donbasu: mistse u zahalnoukrainskomu masshtabi, problemy ta perspektyvy. [Tourism and recreation potential of Donbass: place on the national scale, problems and prospects]. Bulletin of DITB, 17, 326-329 [in Ukrainian].

12. Sait Luhanskoi ODA (2018). [The site of the Lugansk Regional State Administration]. Retrieved from http://loga.gov.ua/ [in Ukrainian].

13. Trachuk, L.M. (2016). Vplyv politychnoi nestabilnosti na rozvytok turystychnoi destynatsii [Influence of political instability on development of tourist destination]. Geography and Tourism: Science. ed. / ed. count Lyubitseva O.O. and others. K.: Alpha-PIC, 37, 26-35 [in Ukrainian].

14. Turystychni potoky v Ukraini za 2013, 2014, 2015, 2016 rr. (2017). [Tourist streams in Ukraine for 2013, 2014, 2015, 2016]. State Statistics Service of Ukraine. Retrieved from http://www.ukrstat.gov.ua/ [in Ukrainian].

Надійшла до редколегї 23.03.2018 р. 